\title{
Relationship between vitamin D and chronic spontaneous urticaria: a systematic review
}

\author{
Papapit Tuchinda ${ }^{1}$, Kanokvalai Kulthanan ${ }^{1 *}$, Leena Chularojanamontri ${ }^{1}$, Sittiroj Arunkajohnsak ${ }^{1}$ \\ and Sutin Sriussadaporn²
}

\begin{abstract}
Background: Vitamin D has been reported to be associated with many allergic diseases. There are a limited number of the studies of vitamin D supplementation in patients with chronic spontaneous urticaria (CSU). This study aims to study the relationship between vitamin D and CSU in terms of serum vitamin D levels, and the outcomes of vitamin D supplementation.
\end{abstract}

Methods: A literature search of electronic databases for all relevant articles published between 1966 and 2018 was performed. The systematic literature review was done following Preferred Reporting Items for Systematic Reviews and Meta-analysis recommendations.

Results: Seventeen eligible studies were included. Fourteen (1321 CSU cases and 6100 controls) were concerned with serum vitamin D levels in CSU patients. Twelve studies showed statistically significant lower serum vitamin $D$ levels in CSU patients than the controls. Vitamin D deficiency was reported more commonly for CSU patients (34.3-89.7\%) than controls (0.0-68.9\%) in 6 studies. Seven studies concerned with vitamin D supplementation in CSU patients showed disease improvement after high-dosages of vitamin D supplementation.

Conclusion: CSU patients had significantly lower serum vitamin D levels than the controls in most studies. However, the results did not prove causation, and the mechanisms were not clearly explained. Despite the scarcity of available studies, this systematic review showed that a high dosage of vitamin D supplementation for 4-12 weeks might help to decrease the disease activity in some CSU patients. Well-designed randomized placebo-controlled studies are needed to determine the cut-off levels of vitamin D for supplementation and treatment outcomes.

\section{Background}

Chronic spontaneous urticaria (CSU) is defined as the occurrence of spontaneous wheals, angioedema, or both for more than 6 weeks [1]. Recommended first-line treatment is modern, second-generation $\mathrm{H}_{1}$-antihistamines. For refractory patients, a short course of systemic corticosteroids, omalizumab or ciclosporin is recommended [1].

*Correspondence: kanokvalai.kul@mahidol.ac.th

${ }^{1}$ Department of Dermatology, Faculty of Medicine Siriraj Hospital, Mahidol University, 2 Wanglang Road, Bangkoknoi, Bangkok 10700,

Thailand

Full list of author information is available at the end of the article
Vitamin D, a fat-soluble vitamin, exists in two forms: $\mathrm{D}_{2}$ (ergocalciferol) and $\mathrm{D}_{3}$ (cholecalciferol) [2]. The human body gains it from the diet and sunlight. Vitamin $\mathrm{D}_{2}$ has been found in some mushrooms, e.g., shiitake mushrooms and button mushrooms. Vitamin $\mathrm{D}_{3}$ is commonly found in halibut, mackerel, eel, salmon, beef liver, and egg yolks [3]. Within the human body, only the skin can produce vitamin $\mathrm{D}_{3}$. Ultraviolet $\mathrm{B}$ radiation (wavelength, 290-315 nm) converts 7-dehydrocholesterol in the skin to previtamin $\mathrm{D}_{3}$, which is rapidly converted to vitamin $D_{3}$. Vitamins $D_{2}$ and $D_{3}$ from diets and vitamin $D_{3}$ from skin photobiosynthesis are initially metabolized by the liver enzyme 25-hydroxylase (CYP2R1) to 25-hydroxyvitamin $\mathrm{D}(25(\mathrm{OH}) \mathrm{D})$, the major circulating metabolite 
which is commonly used for evaluation of vitamin D status. The $25(\mathrm{OH}) \mathrm{D}$ is metabolized in the kidneys by the enzyme 25 -hydroxyvitamin $\mathrm{D}-1 \alpha$-hydroxylase (CYP27B1) to 1,25-dihydroxyvitamin $\mathrm{D}\left(1,25(\mathrm{OH})_{2} \mathrm{D}\right)$, the most biologically active form of vitamin $\mathrm{D}$ [2].

Vitamin D plays a major role in mineral homeostasis [2]. Besides its role in bone physiology, it also has a role on cutaneous immunity by binding to its nuclear receptors and plasma membrane receptors of epithelial cells, and to various cells such as mast cells, monocytes, macrophages, T-cells, B-cells, and dendritic cells $[4,5]$. In the innate immune system, vitamin D contributes to improving antimicrobial defenses by stimulating the expression of antimicrobial peptides such as cathelicidin and human $\beta$-defensin [6]. In the adaptive immune system, in vitro study showed that physiologic (in vivo) concentration of $25(\mathrm{OH}) \mathrm{D}_{3}$ in serum-free medium can activate $\mathrm{T}$ cells to express CYP27B1 and then convert $25(\mathrm{OH}) \mathrm{D}_{3}$ to $1,25(\mathrm{OH})_{2} \mathrm{D}_{3}$. (active form of vitamin $\mathrm{D}$ ) [7]. Vitamin $\mathrm{D}$ can suppress dendritic cell maturation and inhibits Th1 cell proliferation by decreasing Th1 cytokine secretion. It also induces hyporesponsiveness by blocking proinflammatory Th17 cytokine secretion and decreasing interleukin (IL)-2 production from regulatory $\mathrm{T}$ (Treg) cells. It inhibits B-lymphocyte function resulting in the reduction of immunoglobulin E production [8, 9]. Moreover, vitamin D has influences on the proliferation, survival, differentiation, and function of mast cells [5, 10].

The vitamin D binding protein (VDBP) and vitamin D receptor (VDR) are two proteins that influence the biological actions. VDBP is the main carrier protein in the circulation. Group-specific component (GC) is the gene that encodes VDBP [11]. Genetic polymorphism in the GC gene influences the concentration of VDBP and its affinity for vitamin D. Regarding VDR, the binding of VDR to vitamin D results in epigenetic modification and transcription of various specific genes [12]. The human VDR gene is located in chromosome 12. Polymorphism in the VDR gene has been shown to alter VDR functions that affect vitamin D activities [13]. Among the VDR polymorphisms, the SNPs rs 1544410 and rs2228570 are frequently studied in association with allergic diseases. However, Nasiri-Kalmarzi et al. reported no significant correlation between the VDR rs2228570 and VDBP rs7041 SNPs and the development of chronic urticaria (CU), although they found a positive correlation between serum VDBP and the progression of CU. They concluded that alteration of the vitamin $\mathrm{D}$ pathway at the gene and protein levels may be a risk factor for the progression of CU [14].

There have been reports of an association between vitamin D and allergic diseases, such as food allergies, rhinosinusitis, recurrent wheeze, asthma, atopic dermatitis, and CSU [15-17]. Some studies have shown that vitamin $\mathrm{D}$ is involved in the etiopathogenesis of CSU, while other studies have demonstrated clinical improvement in CSU with vitamin D supplements. However, there are a limited number of studies on this issue, and their results are inconsistent. [14, 18-33].

We performed a systematic review to examine the serum vitamin D levels in patients with CSU. Data concerning vitamin D supplementation in the CSU patients were also studied to determine whether supplementation impacts treatment outcomes.

\section{Methods}

\section{Search strategy and selection criteria}

This systematic review adhered to Preferred Reporting Items for Systematic Reviews and Meta-analysis recommendations (PRISMA).

A literature search of electronic databases (PubMed, Scopus, Web of Science, MEDLINE, The Cochrane Library, and CINAHL) for all relevant articles published between Jan 1, 1966, and September 30, 2018 was conducted using the search term "chronic urticaria and vitamin D or $25(\mathrm{OH}) \mathrm{D}$ insufficiency or deficiency or 1,25 $(\mathrm{OH})_{2}$ vitamin D insufficiency or deficiency" The titles and abstracts of the articles identified in the search were screened by two independent reviewers (KK and SA) for eligibility based on the inclusion criterion. Full texts were then obtained and assessed for eligibility by those two reviewers (KK and SA). A further manual search of the references cited in the selected articles was subsequently performed to identify any relevant studies that might have been missed in the initial search. Finally, all yielded relevant reports were systematically reviewed (Fig. 1).

Any types of publication involving vitamin D in CSU patients were included in our systemic review. The exclusion criteria were: (1) articles that were not published in English; (2) duplicated publications; (3) studies published only in abstract form; and (4) continuous medical education (CME) and review articles.

\section{Assessment of risk of bias in included studies}

Two investigators (KK and SA) assessed the risk of bias of the eligible studies included in this systematic review. We used Cochrane Collaboration's tool to assess the risk of bias in randomized controlled trials (RCTs). The Risk Of Bias In Non-randomized Studies-of Interventions (ROBINS-I) tool was used to assess the risk of bias in non-RCT studies.

\section{Data extraction for serum vitamin D levels and CSU}

The search strategies were mainly used to identify vitamin D levels, and to compare the levels found in CSU patients and controls. Serum vitamin D levels are mostly 

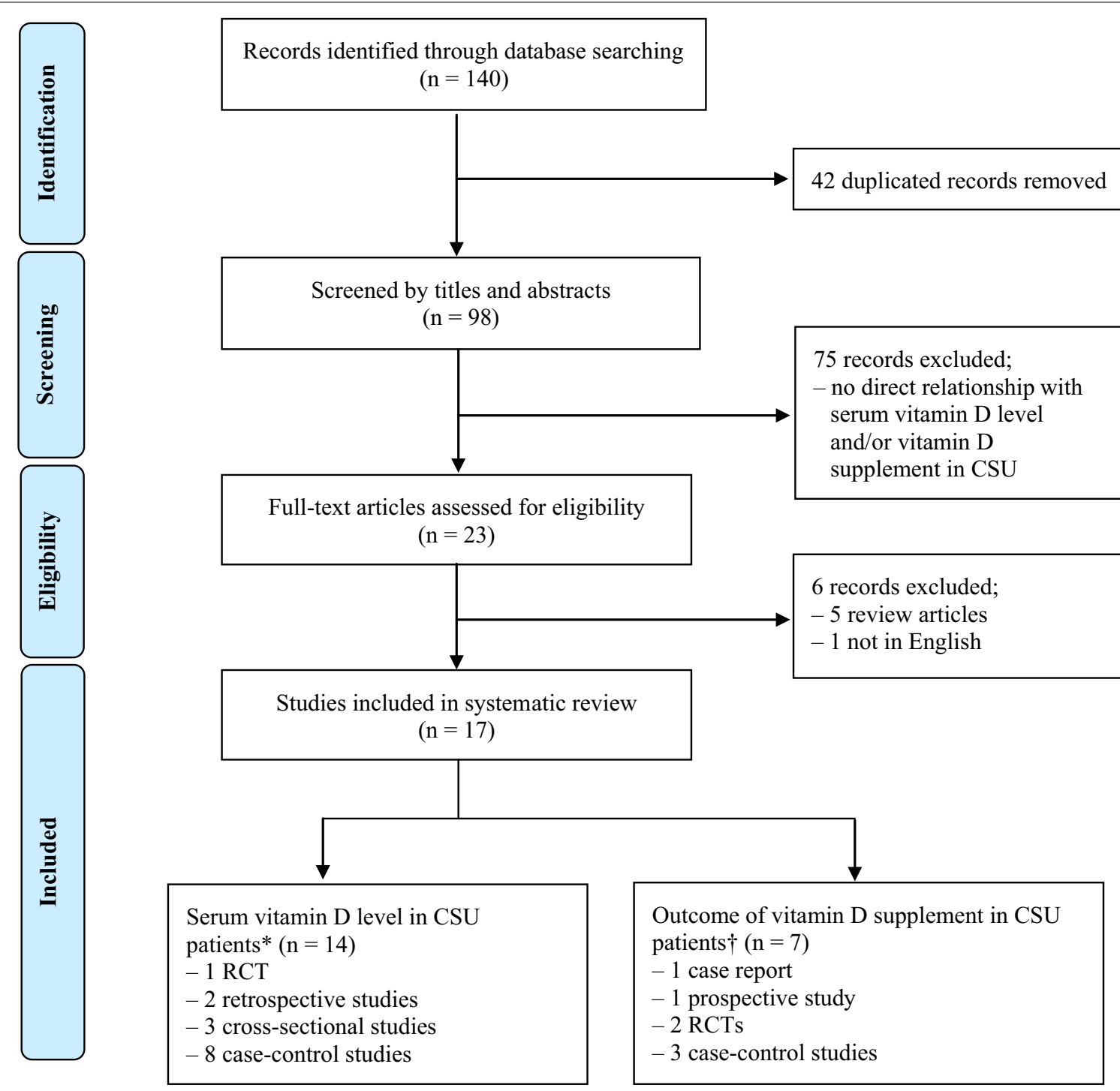

Fig. 1 Flow diagram of literature review in this study. Seventeen studies met the inclusion criteria and were included in our systematic review. *Of the 14 studies, the relation between serum vitamin D level and CSU were assessed [14, 18, 20-25, 28-33]. ${ }^{\dagger}$ In 7 studies, various severity assessment were used to evaluate the effect of vitamin D supplementation in CSU patients [19, 24-27, 31, 32]. CSU chronic spontaneous urticaria

reported in the form $25(\mathrm{OH}) \mathrm{D}$. After the eligible full-text articles were reviewed and the relevant data reported in those articles were further searched, the following information was extracted from each: the first author, year of publication, type of study, number and characteristics of the population, number of cases and controls, method of vitamin D measurement, type (form) and unit of the measured serum vitamin $D$, vitamin $D$ levels in case and control groups, and study outcomes. Information was completely and carefully extracted from the eligible articles.

\section{Data extraction for treatment or supplementation of vitamin D}

We also examined whether vitamin D supplementation has an impact on the outcomes of urticaria treatment. All relevant data were extracted, namely, the first author, year of publication, type of study, number and characteristics of cases and/or controls, form, dosage and duration of vitamin D treatment, assessment duration, methods and parameters for outcome measurement, vitamin $\mathrm{D}$ status at baseline and after vitamin D treatment, and treatment outcomes. 


\section{Results}

\section{Literature search}

The detailed steps of the literature search are illustrated in the flow chart at Fig. 1. A total of 140 potentially relevant studies were found. The titles and abstracts of these articles were reviewed. Of the 117 excluded studies, 42 were removed due to duplication and 75 were irrelevant; the remainder (23 studies) were screened for full text review. According to the inclusion and exclusion criteria, 5 review articles were excluded, and 1 study was excluded because it had not been published in English. The full texts of the remaining 17 studies were extensively reviewed, and all were finally included [14, 18-33].

\section{Characteristics of included studies}

The 17 studies were published during the period 20102018 [14, 18-33]. The main characteristics of the studies were summarized into two issues: serum vitamin D levels in CSU patients, and outcomes of vitamin D supplementation in CSU patients.

\section{Risk of bias}

Three RCTs in our systematic review were estimated mainly at low risk. The majority of the non-RCT studies had a low risk of bias according to ROBIN-I assessment.

\section{Serum vitamin D levels in CSU patients}

Fourteen studies were concerned with serum vitamin D levels in CSU patients. There were 1 RCT [32], 3 crosssectional studies [20, 22, 33], 8 case-control studies [14, $18,21,23-25,28,31]$, and 2 retrospective reviews [29, 30] (Table 1). All studies drew upon data from a total of 7421 participants, with 1321 patients with CSU and 6100 controls, including 5456 healthy controls, and 25 cases of allergic rhinitis controls. The remaining 619 participants were 593 acute urticaria patients and 26 atopic dermatitis patients. Statistical analyses for meta-analysis were not performed due to the substantial heterogeneity of the reported data.

The methods used for the measurement of vitamin $\mathrm{D}$ varied among the studies (Table 1 ). All of the studies reported the serum vitamin D level as $25(\mathrm{OH}) \mathrm{D}$ except two: one study by Woo et al. [29], which measured $25(\mathrm{OH}) \mathrm{D}_{3}$, and Nasiri-Kalmarzi's study, which did not report the type of vitamin D measured [14]. The units of serum $25(\mathrm{OH}) \mathrm{D}$ were reported mainly in $\mathrm{ng} / \mathrm{mL}[14,20-$ $23,25,28,29,31,33]$, but some studies reported them in $\mu \mathrm{g} / \mathrm{L}[24]$ and nmol/L [18, 30, 32].

The main outcomes of the serum vitamin D levels in the CSU patients compared to the controls are summarized at Table 2 . Twelve studies showed statistically significantly lower levels of serum vitamin D in the CSU patients than the controls $[14,18,20,21,23-25,28$, $29,31,33]$. Wu et al. showed significantly higher levels of serum vitamin D in the CSU patients [30]. They compared the serum vitamin D levels of CSU patients in Southampton General Hospital to those of the general United Kingdom (UK) population (data from the National Diet and Nutrition Survey). The serum vitamin D levels of the 225 CSU patients were significantly higher than those of the 1321 UK population (control group). Lee et al. conducted a cross-sectional, population-based study of Korean children (aged 4-13 years; 3159 were controls; 624 had current urticaria, of which 57 were CSU and 567 acute urticaria). There was no statistically significant difference in the serum vitamin D levels of the CSU patients and the controls $(p=0.124)$ [22].

\section{Degree of severity of serum vitamin D levels in CSU patients}

The serum vitamin D levels were categorized into subgroups according to the vitamin D status. Serum $25(\mathrm{OH})$ D levels of $>30 \mathrm{ng} / \mathrm{mL}, 20-30 \mathrm{ng} / \mathrm{mL}$, and $<20 \mathrm{ng} / \mathrm{mL}$ were defined as sufficiency, insufficiency, and deficiency, respectively; levels of $<10 \mathrm{ng} / \mathrm{mL}$ indicated a critically low or severe deficiency. The cut-point values to define vitamin $\mathrm{D}$ status in each study were very similar even though slightly different values were found in some studies (Table 3). The prevalence of vitamin D deficiency was reported more commonly in the CSU patients (34.3$89.7 \%)$ than in the controls $(0.0-68.9 \%)$ in 8 studies [21, $23,24,28,29,31-33]$. Four of those studies reported statistically significant differences $[21,24,29,31]$.

\section{Other effects of vitamin D on CSU}

The effects of vitamin D on CSU are summarized at Table 2. The studies also compared the serum vitamin D levels of the CSU patients with those of patients with other diseases, such as acute urticaria [22, 29], atopic dermatitis [29], and allergic rhinitis [28]. Vitamin D level was significantly lower in CSU patients than in atopic dermatitis and allergic rhinitis [28, 29]. Four out of 11 studies reported significant association between low serum vitamin $\mathrm{D}$ levels and high disease activity whereas seven studies did not find this significant association. Most studies demonstrated that there was no association between low serum vitamin D levels and disease duration $[18,21,28,32,33]$. Others reported a relationship between the serum vitamin $\mathrm{D}$ levels and other investigations, including erythrocyte sedimentation rate [20,31], C-reactive protein [21], serum IgE [14, $18,23,24,32]$, IL-17 [20], transforming growth factor- $\beta 1$ [20], thyroid autoantibodies [24, 28], autologous serum skin test [14, 21, 28, 29, 33], and autologous plasma skin test [20]. It was shown that low serum vitamin D level 


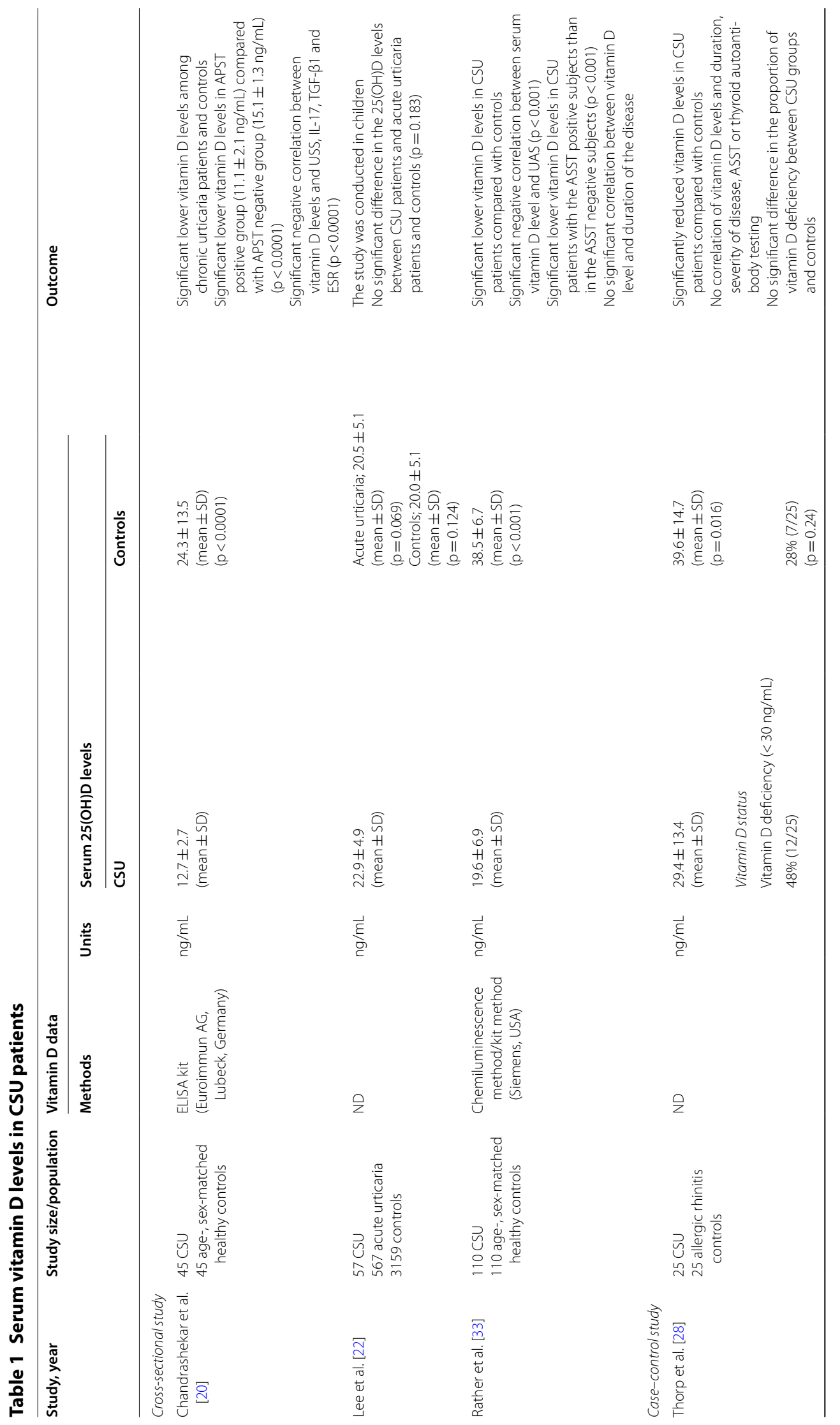




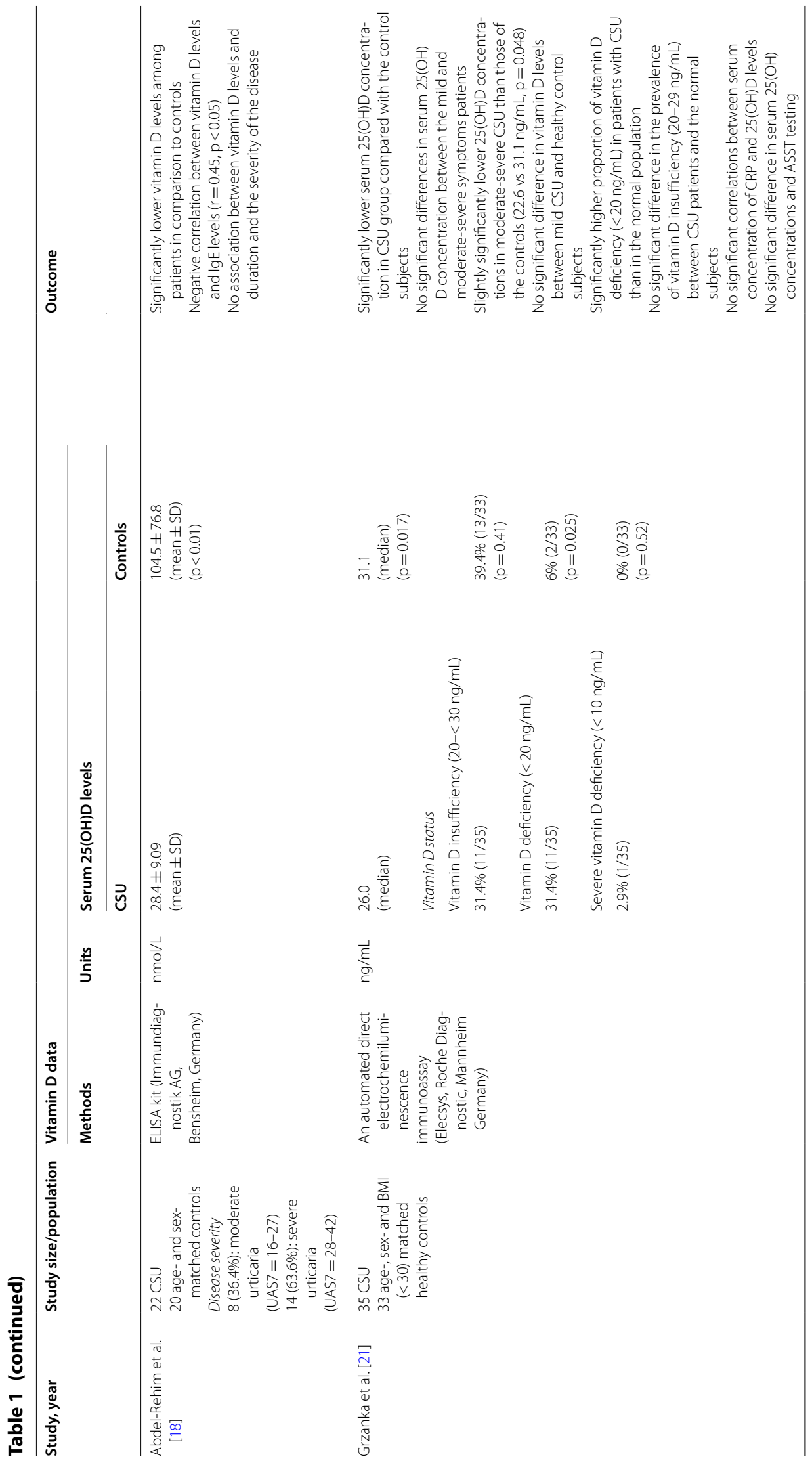




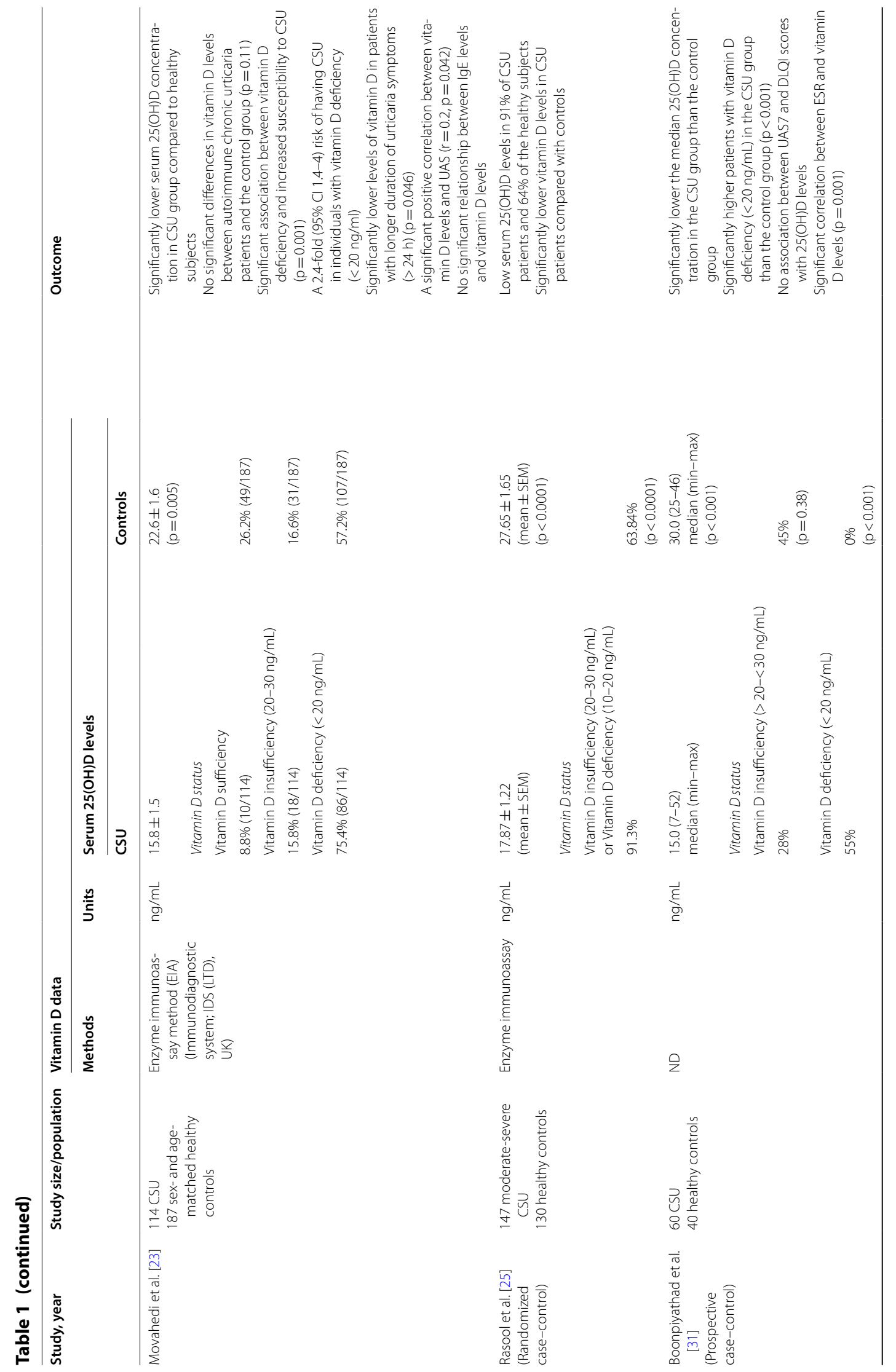




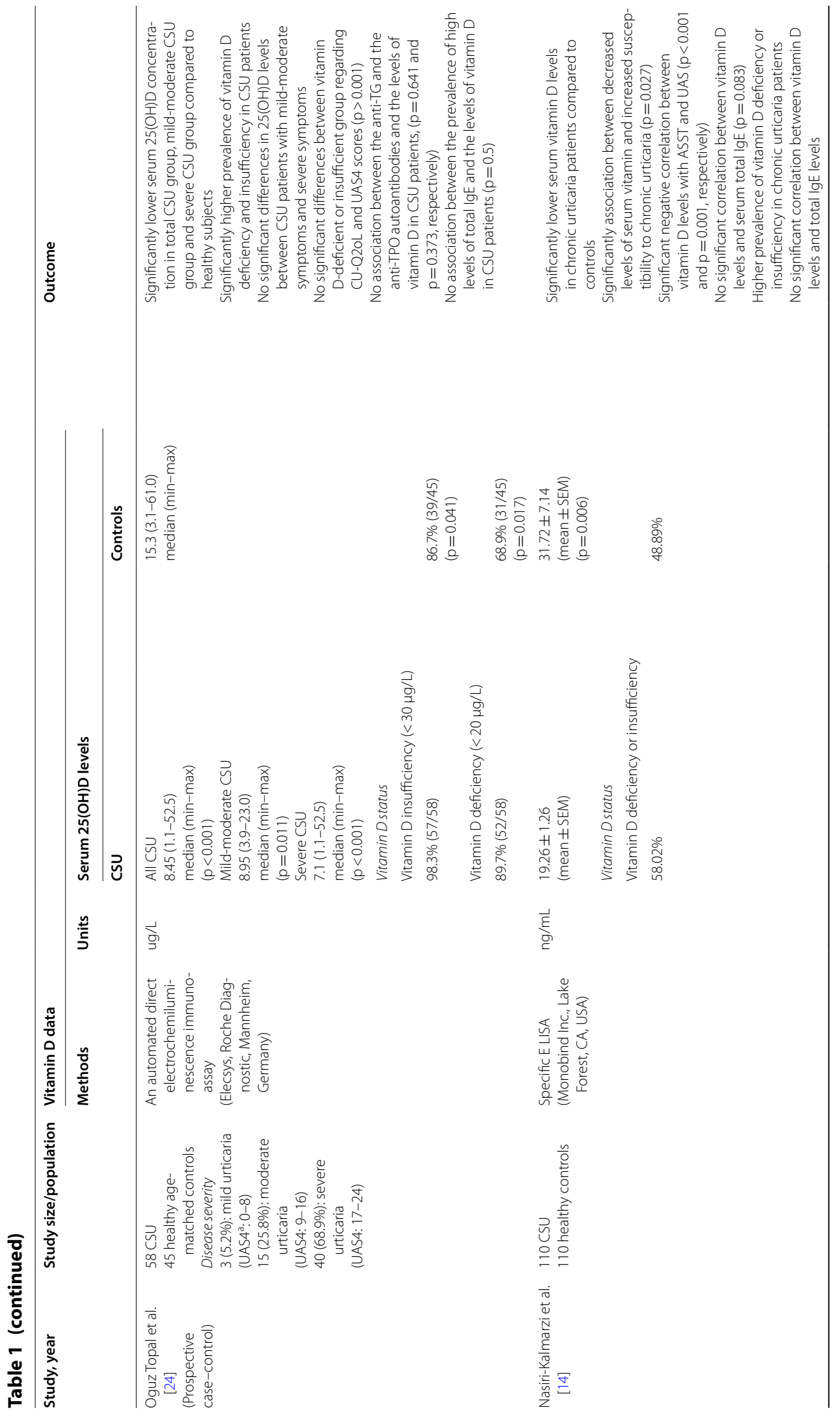




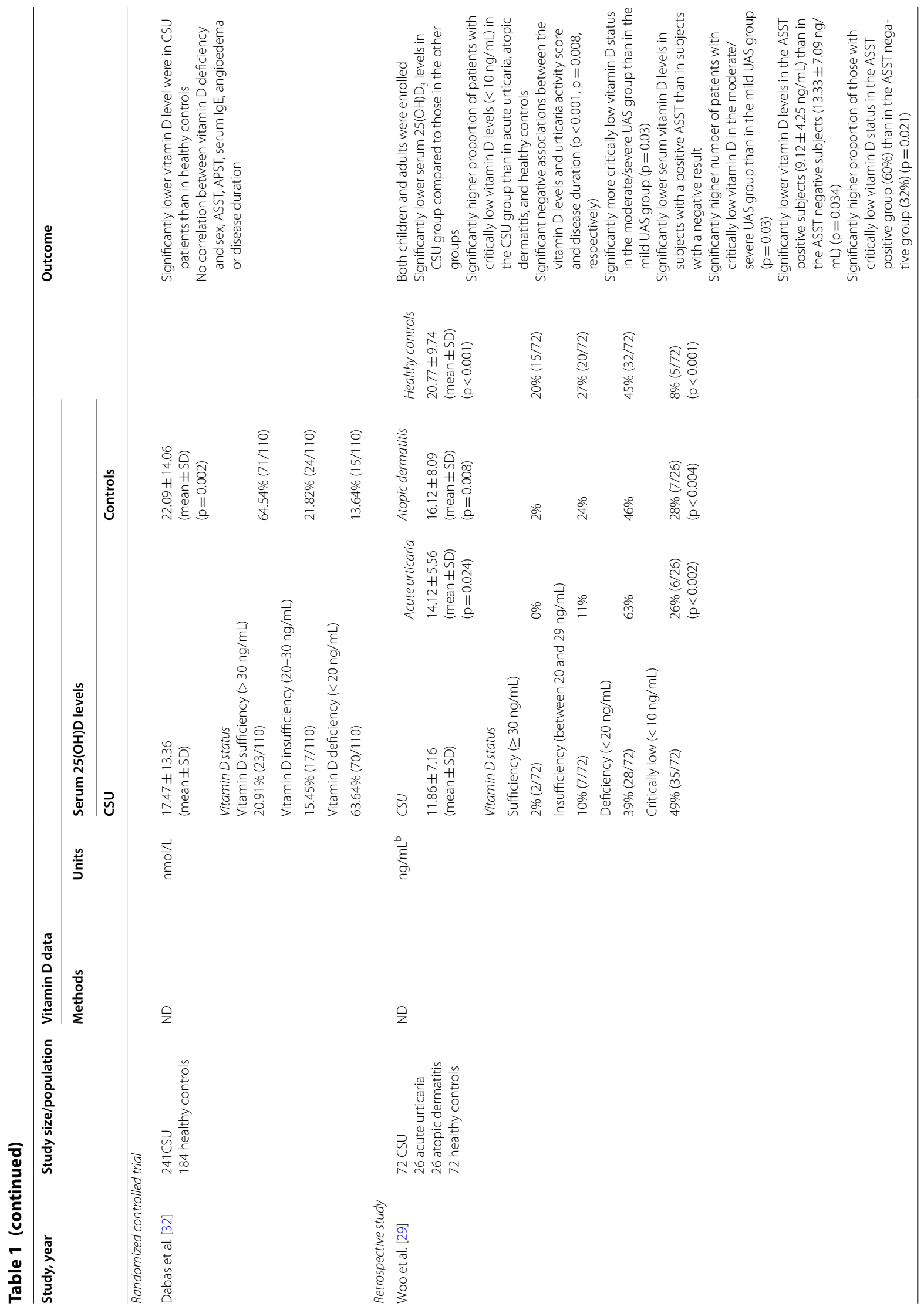




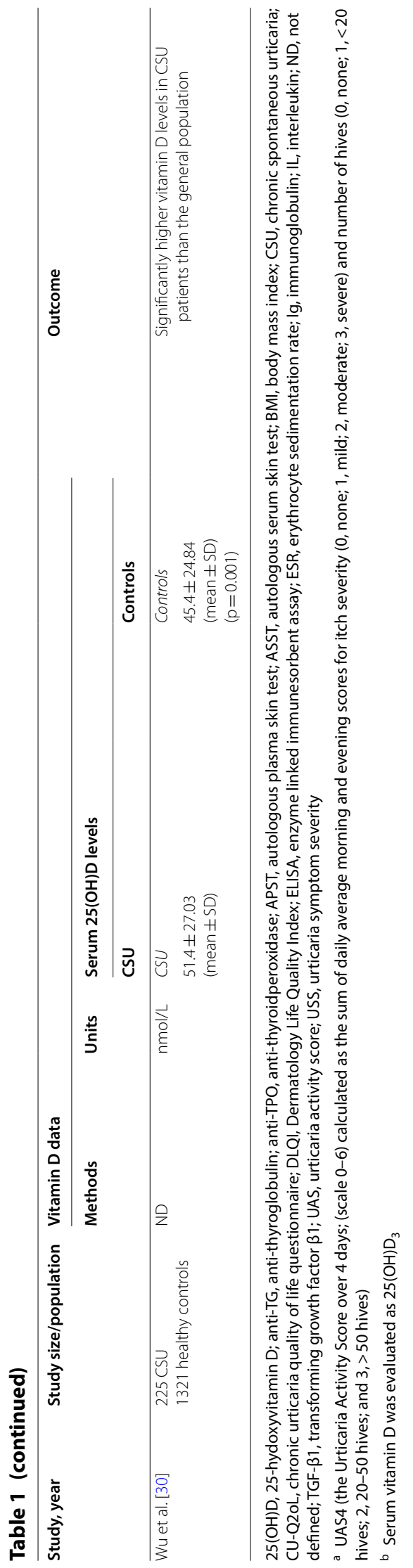


Table 2 Summary of parameters of vitamin D in CSU

\begin{tabular}{|c|c|c|c|c|}
\hline Outcome measurement & Pro & Cons & Results & References \\
\hline \multirow[t]{3}{*}{$\begin{array}{l}\text { Lower serum vitamin D levels in CSU patients than } \\
\text { healthy controls }\end{array}$} & & $\checkmark$ & $\begin{array}{l}\text { One study showed significantly higher levels of vita- } \\
\text { min D in CSU patients than that of controls }\end{array}$ & Wu et al. [30] \\
\hline & - & - & $\begin{array}{l}\text { One study showed no significant difference in } \\
\text { vitamin D levels between CSU patients and that of } \\
\text { controls }\end{array}$ & Lee et al. [22] \\
\hline & $\checkmark$ & & $\begin{array}{l}\text { Twelve studies showed significant lower levels of vita- } \\
\text { min D in CSU patients than that of controls }\end{array}$ & $\begin{array}{l}\text { Thorp et al. [28] } \\
\text { Grzanka et al. [21] } \\
\text { Chandrashekar et al. [20] } \\
\text { Abdel-Rehim et al. [18] } \\
\text { Movahedi et al. [23] } \\
\text { Woo et al. [29] } \\
\text { Rasool et al. [25] } \\
\text { Boonpiyathad et al. [31] } \\
\text { Oguz Topal et al. [24] } \\
\text { Nasiri-Kalmarzi et al. [14] } \\
\text { Dabas et al. [32] } \\
\text { Rather et al. [33] }\end{array}$ \\
\hline \multirow[t]{3}{*}{$\begin{array}{l}\text { Vitamin D insufficiency in CSU patients more than in } \\
\text { controls }\end{array}$} & & $\checkmark$ & $\begin{array}{l}\text { One study showed significantly higher prevalence of } \\
\text { vitamin D insufficiency in controls than in CSU }\end{array}$ & Movahedi et al. [23] \\
\hline & & $\checkmark$ & $\begin{array}{l}\text { Two studies showed no significant difference in the } \\
\text { prevalence of vitamin D insufficiency between CSU } \\
\text { patients and controls }\end{array}$ & $\begin{array}{l}\text { Grzanka et al. [21] } \\
\text { Boonpiyathad et al. [22] [31] }\end{array}$ \\
\hline & $\checkmark$ & & $\begin{array}{l}\text { One study showed significant difference in the } \\
\text { prevalence of vitamin D insufficiency between CSU } \\
\text { patients and controls }\end{array}$ & Oguz Topal et al. [24] \\
\hline \multirow[t]{3}{*}{$\begin{array}{l}\text { Vitamin D deficiency in CSU patients more than in } \\
\text { controls }\end{array}$} & - & - & $\begin{array}{l}\text { One study showed no significant difference in the } \\
\text { prevalence of vitamin D deficiency between CSU } \\
\text { patients and controls }\end{array}$ & Thorp et al. [28] \\
\hline & $\checkmark$ & & $\begin{array}{l}\text { Three studies showed significant difference in the } \\
\text { prevalence of vitamin D deficiency between CSU } \\
\text { patients and controls }\end{array}$ & $\begin{array}{l}\text { Grzanka et al. [21] } \\
\text { Boonpiyathad et al. [31] } \\
\text { Oguz Topal et al. [24] }\end{array}$ \\
\hline & $\checkmark$ & & $\begin{array}{l}\text { One study show significant difference in the propor- } \\
\text { tion of critically low vitamin D levels in the CSU } \\
\text { patients and in acute urticaria, atopic dermatitis, } \\
\text { and healthy controls }\end{array}$ & Woo et al. [29] \\
\hline \multirow[t]{2}{*}{$\begin{array}{l}\text { Lower serum vitamin D levels between CSU and } \\
\text { acute urticaria }\end{array}$} & & $\checkmark$ & $\begin{array}{l}\text { One study showed no significant difference levels } \\
\text { of vitamin D between CSU and acute urticaria } \\
\text { patients }\end{array}$ & Lee et al. [22] \\
\hline & $\checkmark$ & & $\begin{array}{l}\text { One study showed significantly lower levels of vita- } \\
\text { min D in CSU than acute urticaria patients }\end{array}$ & Woo et al. [29] \\
\hline $\begin{array}{l}\text { Lower serum vitamin D levels between CSU and } \\
\text { atopic dermatitis }\end{array}$ & $\checkmark$ & & $\begin{array}{l}\text { One study showed significantly lower levels of vita- } \\
\text { min D in CSU than atopic dermatitis }\end{array}$ & Woo et al. [29] \\
\hline $\begin{array}{l}\text { Lower serum vitamin D levels between CSU and } \\
\text { allergic rhinitis }\end{array}$ & $\checkmark$ & & $\begin{array}{l}\text { One study showed significantly lower levels of vita- } \\
\text { min D in CSU than allergic rhinitis }\end{array}$ & Thorp et al. [28] \\
\hline \multirow[t]{3}{*}{$\begin{array}{l}\text { Low serum vitamin D levels and higher disease } \\
\text { activity }\end{array}$} & & $\checkmark$ & $\begin{array}{l}\text { One study reported a significant positive correlation } \\
\text { between vitamin D levels and urticaria activity } \\
\text { score }\end{array}$ & Movahedi et al. [23] \\
\hline & - & - & Six studies reported no association & $\begin{array}{l}\text { Thorp et al. [28] } \\
\text { Abdel-Rehim et al. [18] } \\
\text { Grzanka et al. [21] } \\
\text { Rorie et al. [26] } \\
\text { Boonpiyathad et al. [31] } \\
\text { Oguz Topal et al. [24] }\end{array}$ \\
\hline & $\checkmark$ & & $\begin{array}{l}\text { Three study reported significant negative association } \\
\text { between vitamin D levels and urticaria activity } \\
\text { score } \\
\text { One study reported significant negative association } \\
\text { between vitamin D levels and urticaria severity } \\
\text { score }\end{array}$ & $\begin{array}{l}\text { Woo et al. [29] } \\
\text { Nasiri-Kalmarzi et al. [14] } \\
\text { Rather et al. [33] } \\
\text { Chandrashekar et al. [20] }\end{array}$ \\
\hline
\end{tabular}


Table 2 (continued)

\begin{tabular}{|c|c|c|c|c|}
\hline Outcome measurement & Pro & Cons & Results & References \\
\hline \multirow[t]{2}{*}{$\begin{array}{l}\text { Low serum vitamin } \mathrm{D} \text { levels and longer disease } \\
\text { duration }\end{array}$} & - & - & Five studies reported no association & $\begin{array}{l}\text { Thorp et al. [28] } \\
\text { Abdel-Rehim et al. [18] } \\
\text { Grzanka et al. [21] } \\
\text { Dabas et al. [32] } \\
\text { Rather et al. [33] }\end{array}$ \\
\hline & $\checkmark$ & & One studies reported significant negative association & Woo et al. [29] \\
\hline Low serum vitamin D levels and high ESR & $\checkmark$ & & Two study reported significant correlation & $\begin{array}{l}\text { Chandrashekar et al. [20] } \\
\text { Boonpiyathad et al. [31] }\end{array}$ \\
\hline Low serum vitamin D levels and high CRP levels & - & - & One study reported no association & Grzanka et al. [21] \\
\hline \multirow[t]{2}{*}{ Low serum vitamin D levels and high lgE levels } & $\checkmark$ & & One study reported negative association & Abdel-Rehim et al. [18] \\
\hline & - & - & Four studies reported no association & $\begin{array}{l}\text { Movahedi et al. [23] } \\
\text { Oguz Topal et al. [24] } \\
\text { Nasiri-Kalmarzi et al. [14] } \\
\text { Dabas et al. [32] }\end{array}$ \\
\hline Low serum vitamin D levels and high IL-17 levels & $\checkmark$ & & One study reported negative association. & Chandrashekar et al. [20] \\
\hline Low serum vitamin $D$ levels and TGF- $\beta 1$ & $\checkmark$ & & One study reported negative association & Chandrashekar et al. [20] \\
\hline $\begin{array}{l}\text { Low serum vitamin D levels and thyroid autoantibod- } \\
\text { ies testing }\end{array}$ & - & - & Two studies reported no association & $\begin{array}{l}\text { Thorp et al. [28] } \\
\text { Oguz Topal et al. [24] }\end{array}$ \\
\hline \multirow[t]{3}{*}{$\begin{array}{l}\text { Low serum vitamin D levels and a positive ASST or } \\
\text { APST }\end{array}$} & $\checkmark$ & & $\begin{array}{l}\text { One study reported significant lower levels of vitamin } \\
\text { D in patients with a positive APST }\end{array}$ & Chandrashekar et al. [20] \\
\hline & $\checkmark$ & & $\begin{array}{l}\text { Three study reported significant lower levels of vita- } \\
\text { min D in patients with a positive ASST. }\end{array}$ & $\begin{array}{l}\text { Woo et al. [29] } \\
\text { Nasiri-Kalmarzi et al. [14] } \\
\text { Rather et al. [33] }\end{array}$ \\
\hline & - & - & $\begin{array}{l}\text { Three studies reported no association between the } \\
\text { ASST-positive and ASST-negative groups }\end{array}$ & $\begin{array}{l}\text { Thorp et al. [28] } \\
\text { Grzanka et al. [21] } \\
\text { Dabas et al. [32] }\end{array}$ \\
\hline
\end{tabular}

APST, autologous plasma skin test; ASST, autologous serum skin test; CRP, C-reactive protein; CSU, chronic spontaneous urticaria; ESR, erythrocyte sedimentation rate; Ig, immunoglobulin; IL, interleukin; TGF- $\beta 1$, transforming growth factor $\beta 1$

was significantly associated with high levels of ESR, IgE, IL-17, and transforming growth factor- $\beta 1[18,20,31]$.

\section{Outcome of vitamin D supplementation on CSU patients}

Seven studies (2 RCTs [26, 32], 3 case-control studies [24, 25, 31], 1 prospective study [19], and 1 case report [27]) were concerned with vitamin D supplementation in 587 CSU patients. The outcomes of the vitamin D supplementation were compared to baseline in 6 studies [19, $24-27,32]$ and to controls in 1 study [31].

The regimens of vitamin D supplementation in each study were reviewed and are summarized at Table 4 . Four studies used vitamin $\mathrm{D}_{3}$ at dosages ranging from 2800 to $75,000 \mathrm{IU} /$ week [24-27], one study used vitamin $\mathrm{D}_{2}$ at a dosage of 140,000 IU/week [31], and another study did not define the form of vitamin $\mathrm{D}$ administered at a dosage of 50,000 IU/week [19]. Similarly, the form of vitamin D supplementation was also not defined in the RCT study but patients were categorized into three groups to receive low-dose $(2000 \mathrm{IU} / \mathrm{d})$, high-dose $(60,000 \mathrm{IU} /$ week), and without vitamin D supplementation, respectively [32]. The duration of the vitamin D supplementations ranged from 4 to 12 weeks. The serum vitamin D levels were evaluated in 4 studies and were reported as 25(OH)D [25-27, 31].

The parameters of treatment outcomes varied among the studies; they comprised the urticaria activity score over 4 days (UAS4) [24, 32], urticaria activity score over 7 days (UAS7) [31], dermatology life quality index [19, 31], chronic urticaria quality of life questionnaire [24], visual analogue scale [25], 5-dimension itch score [25], and urticaria symptom severity score $[19,26]$ (Table 5). Four studies reported a significant reduction in disease activity after high dose vitamin D supplementation (vita$\min \mathrm{D}_{2}, 140,000 \mathrm{IU} /$ week; vitamin $\mathrm{D}_{3}, 60,000-75,000 \mathrm{IU} /$ week; and unknown form of vitamin D, 50,000 unit/week) $[19,24,25,31]$. One case report showed that treatment with a low vitamin D dosage (400 IU/d) for 2 months did not reduce urticaria activity. However, complete resolution without antihistamine was demonstrated at a higher dosage (2000 IU/d) [27]. Another study reported a significant reduction in disease activity after high-dose vitamin D supplementation (4000 IU/d) compared to low-dose vitamin D supplementation (600 IU/d) [26]. Ariaee et al. reported that the transforming growth factor- $\beta$, IL-10 and IL-17 expressions were decreased after 8 weeks of vitamin D supplementation [19]. In addition, forkhead 


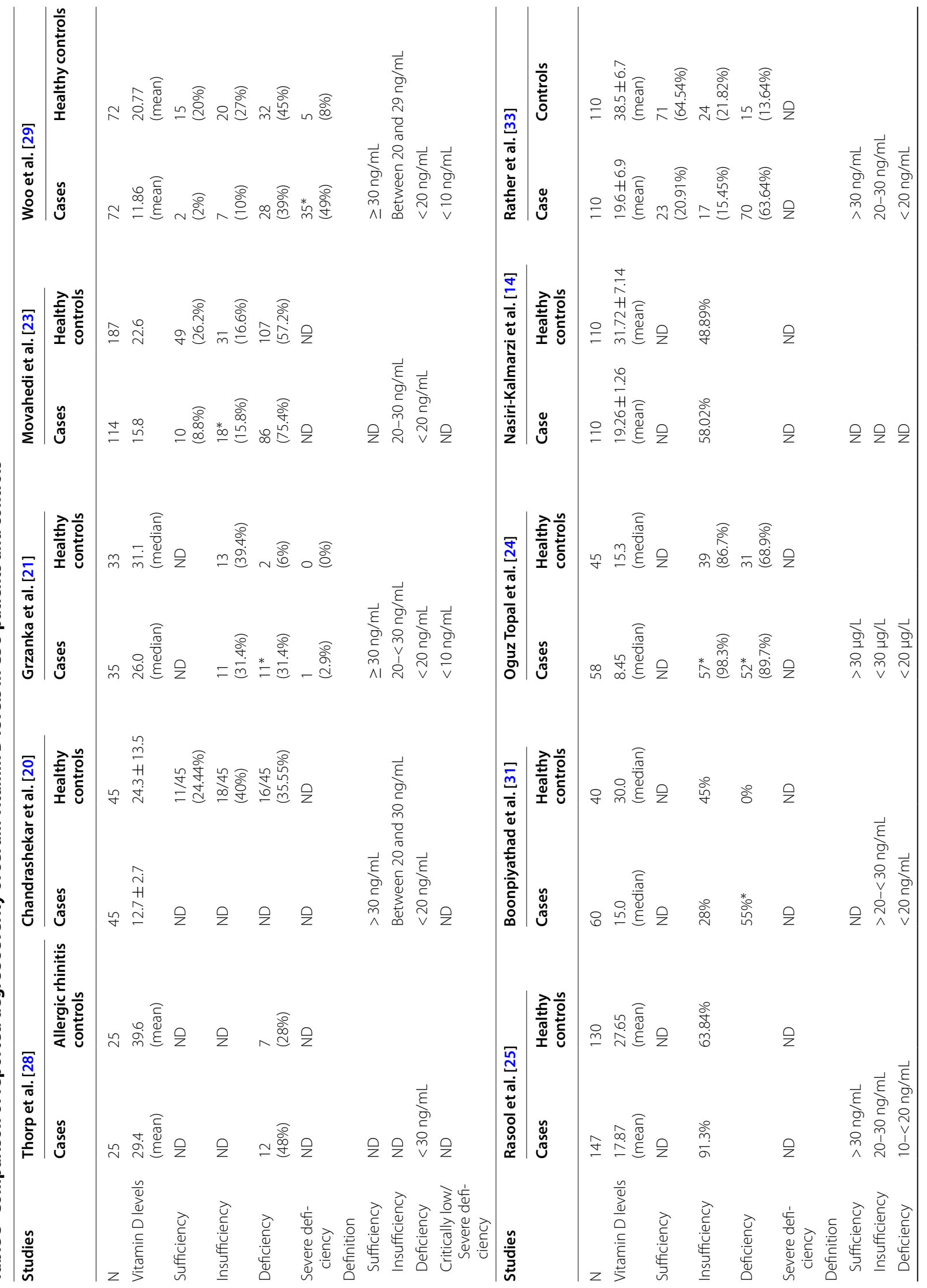




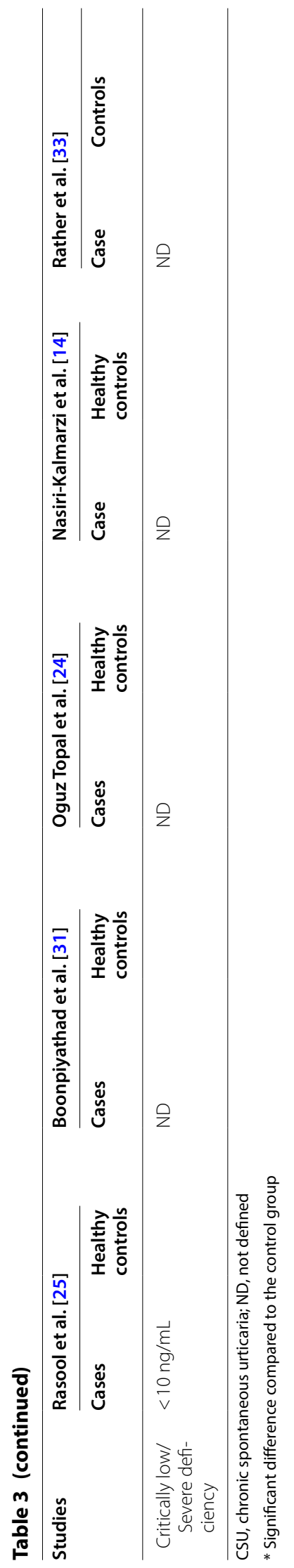




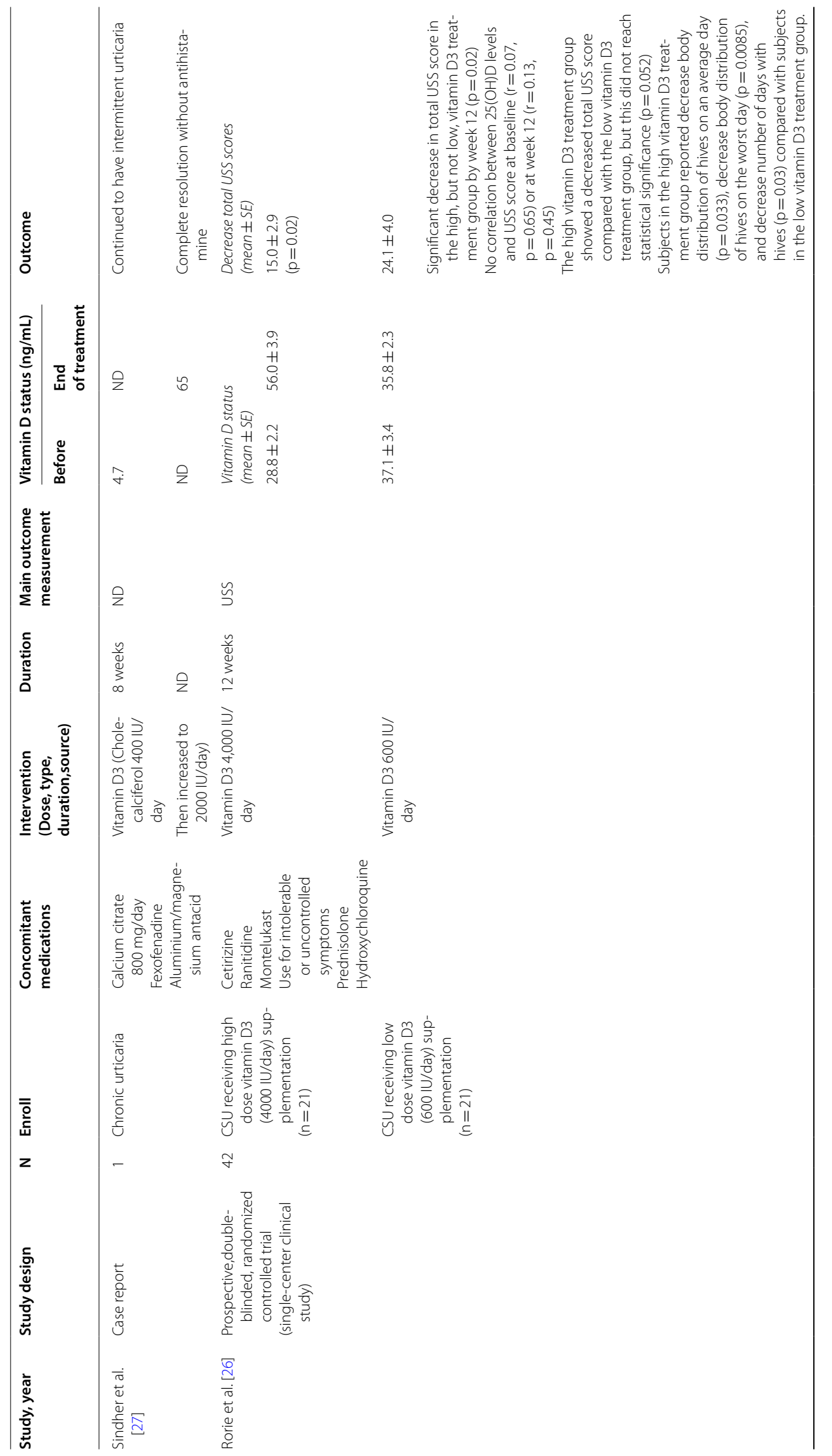




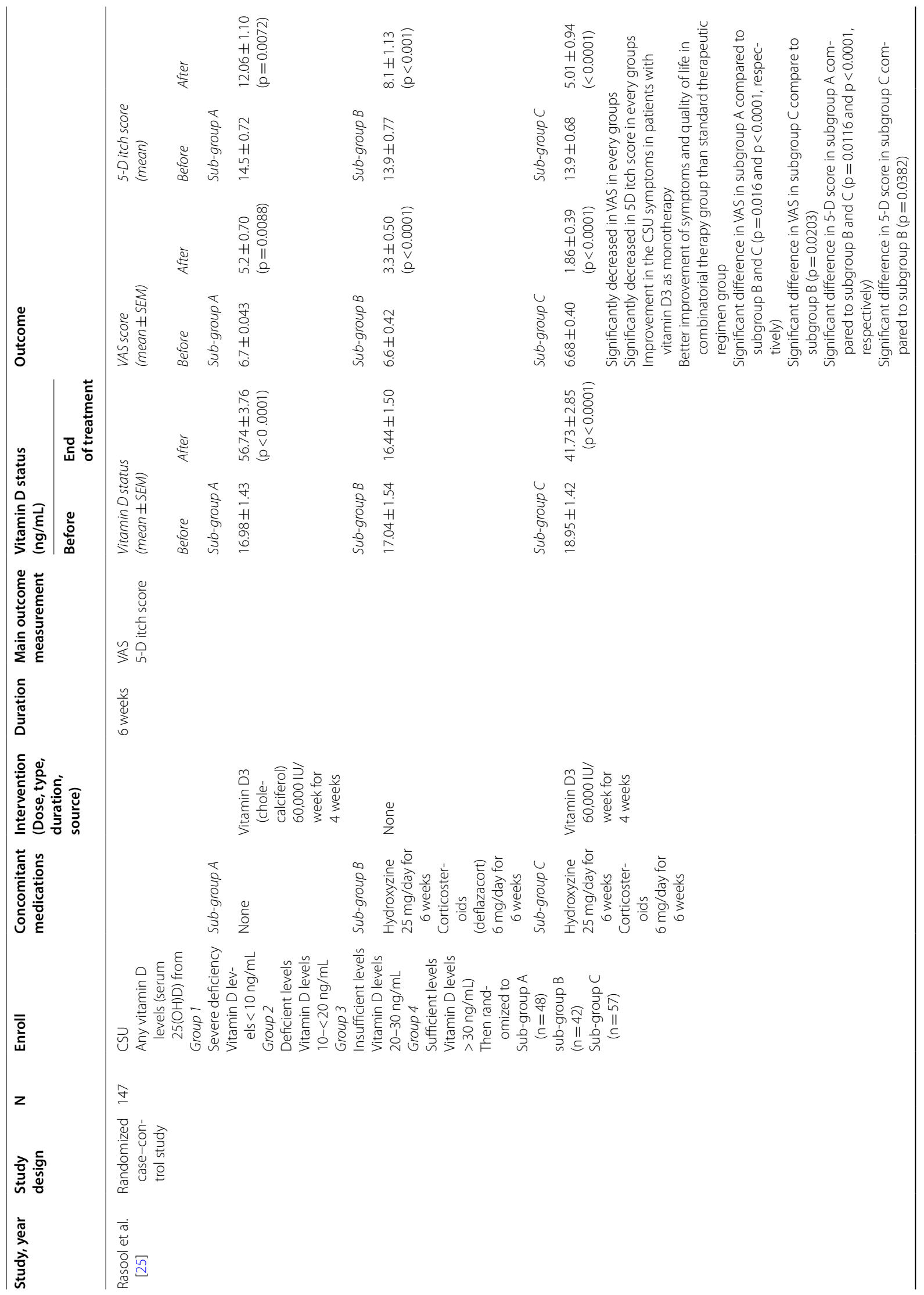




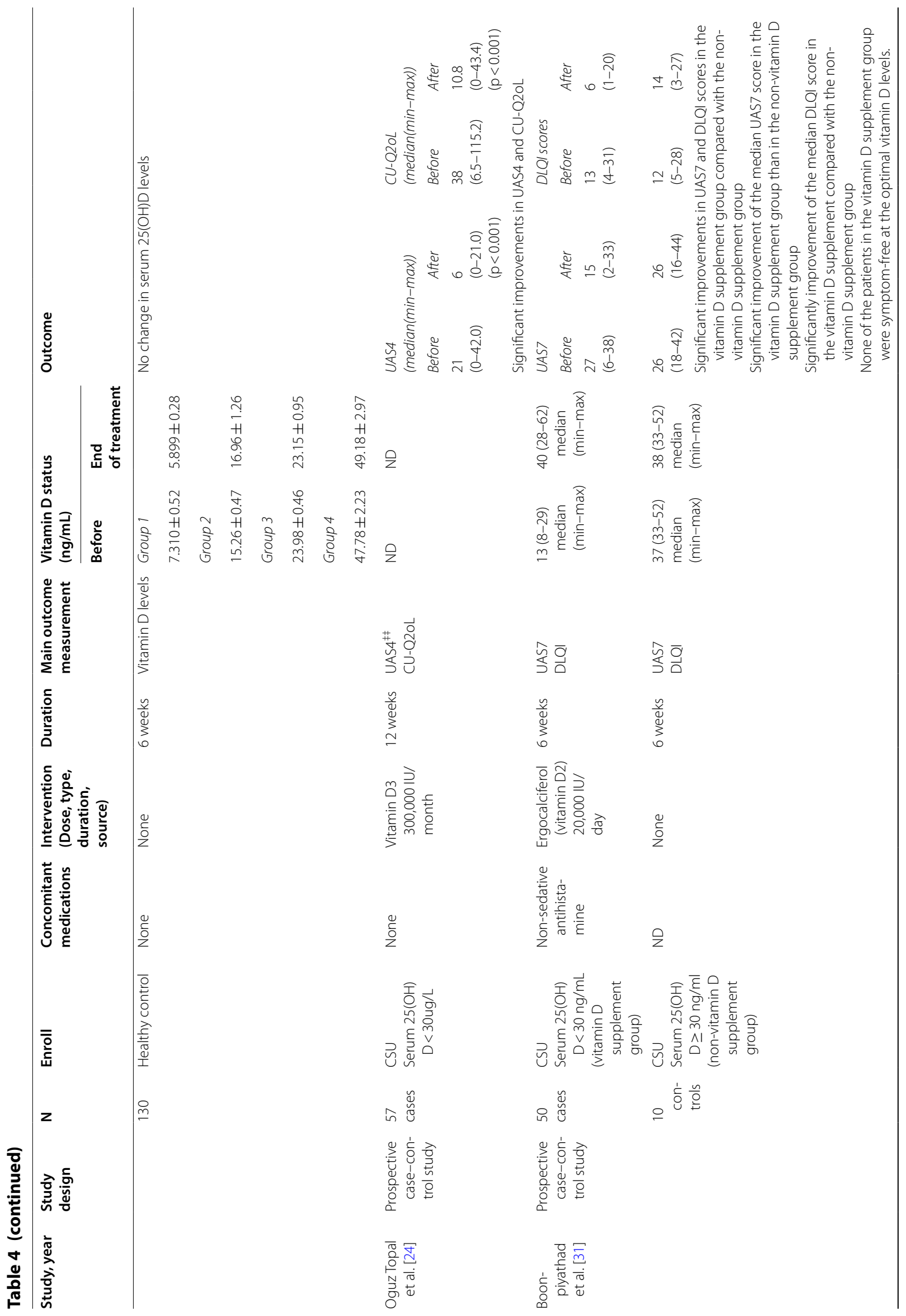




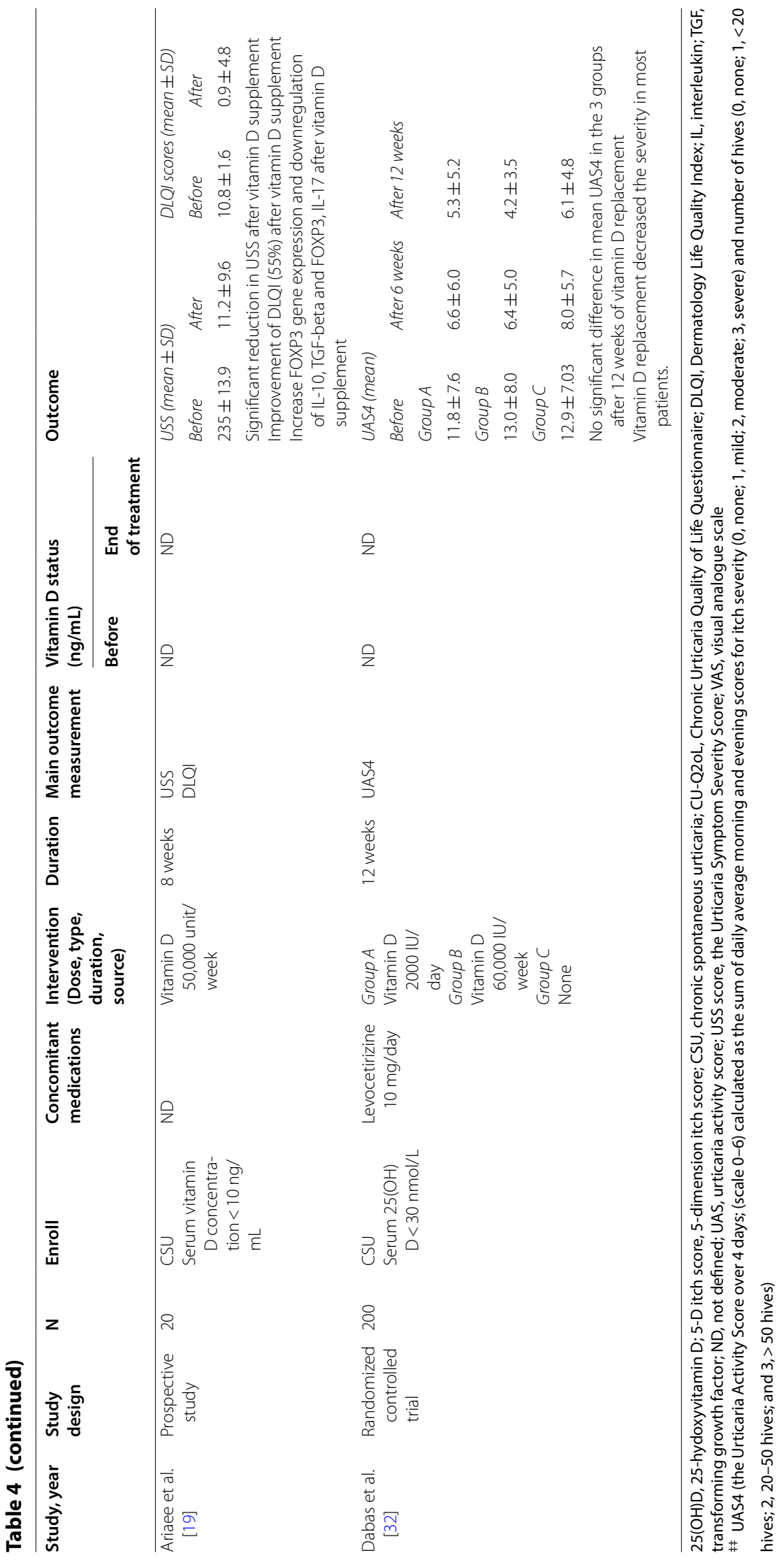




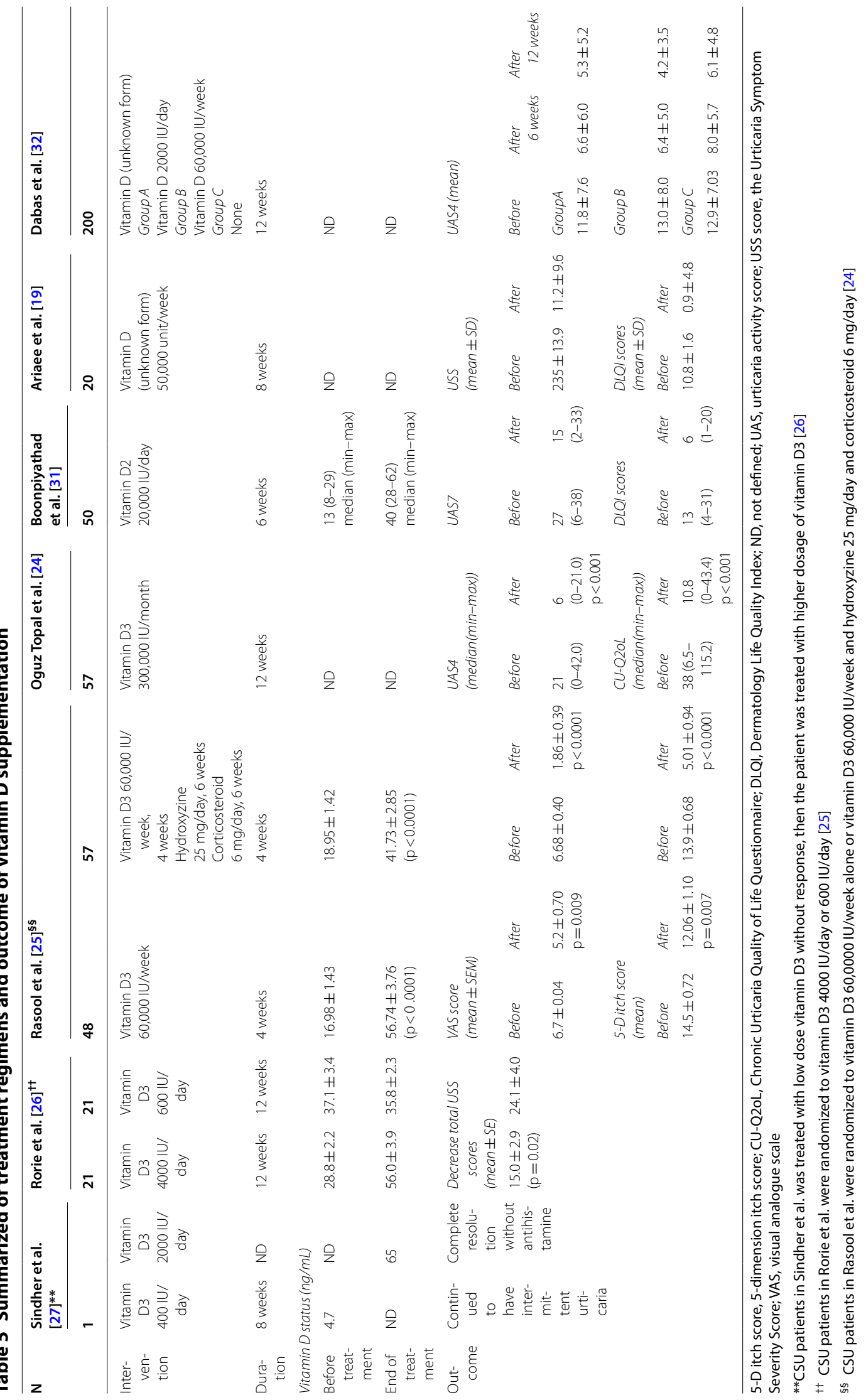


box P3 (FOXP3) expression, a clinical determinant of Treg, increased after treatment [19]. In the RCT study, either low-dose or high-dose of vitamin D supplementation could reduce disease severity but there was no significant difference in the mean UAS4 among the three groups after 12 weeks of supplementation [32].

\section{Discussion}

Two recent meta-analysis regarding the association between vitamin $\mathrm{D}$ and urticaria have been published in 2018. Tsai et al. and Wang et al. showed that the prevalence of vitamin $\mathrm{D}$ was significantly higher in CU patients than that of controls. [34, 35] Similar to those two metaanalysis, 12 out of 14 studies in our study showed significantly lower levels of serum vitamin D in CSU patients than in the controls $[14,18,20,21,23-25,28,29,31,33]$. Only Wu et al. found significantly higher levels of vitamin $\mathrm{D}$ in the CSU patients than in the UK general population as a control group [30]. However, that study compared CSU patients in Southampton General Hospital to the UK general population rather than healthy controls in Southampton; a variation of serum vitamin D levels in different regions of UK was reported [36]. Lee et al. [22] reported no statistical significance between the vitamin D levels in pediatric CSU patients and the controls, which was similar to a study by Tsai et al. [34]. Nevertheless, it should be noted that our study provides additional information regarding associations between vitamin D and urticaria than those of the two studies. Data regarding (1) types of serum vitamin D (2) outcome of vitamin D supplementation after treating with different dosages, types and duration of vitamin $\mathrm{D}$ are also added in this study.

Potential factors determining vitamin D status include oral vitamin D intake, sun exposure, latitude, season, Fitzpatrick skin type, time spent outdoors, sun exposure practices, body mass index (BMI), physical activity, alcohol intake, and genetic polymorphism [37]. Higher serum vitamin $\mathrm{D}$ levels can be observed with prolonged sun exposure, increased time spent outdoors, the summer season, living in lower latitudes, increased physical activity, moderate alcohol intake, and rs7041 gene polymorphism [37]. In contrast, lower serum vitamin D levels can be observed with darker skin, female gender, higher BMI, excessive alcohol intake, and rs 4588 gene polymorphism [37]. It has been reported that vitamin D deficiency and insufficiency is a pandemic problem. The prevalence of vitamin D deficiency and insufficiency has been estimated to be $30 \%-60 \%$ of children and adults worldwide. Areas that had high prevalence of vitamin D deficiency and insufficiency in the general population were Europe (92\%), Middle East (90\%), Asia (45-98\%), and Canada (61\%). The most common cause of vitamin D deficiency and insufficiency is an insufficient exposure to sun-light as diet with fortified vitamin $\mathrm{D}$ are few. For example, in Middle East, vitamin D deficiency is found to strongly correlate with well-covering clothes [38, 39].

Vitamin D has been shown to be linked to other skin diseases. Low serum 25(OH)D levels have been reported in severe atopic dermatitis [40], psoriasis [41], vitiligo [42], systemic sclerosis [43], severe alopecia areata [44], severe systemic lupus erythematosus (SLE) [45], and acne [46] and also associated with an increased risk of cutaneous bacterial infections in vitro [47]. However, no studies in our review reported the cut-off serum vitamin D levels that might be associated with the development of CSU.

As to vitamin $D$ supplementation, both vitamins $D_{2}$ and $\mathrm{D}_{3}$ are commonly. Current dietary reference intakes for vitamin D are $400 \mathrm{IU}$ per day in infancy, $600 \mathrm{IU}$ per day in the 1-70 year age group, and 800 IU per day for individuals aged over 70 [48]. Vitamin $\mathrm{D}_{2}$ is reported to be less effective than vitamin $D_{3}$ in raising total serum vitamin $\mathrm{D}$ levels, but less toxic than vitamin $\mathrm{D}_{3}$ when given in large amounts [2]. The variations in the vitamin D supplementation regimens in the studies might have led to different outcomes.

Six studies showed that a high dosage of vitamin D treatment resulted in a significant reduction in CSU activity. [19, 24-27, 31] The other study reported that vitamin D supplement $2000 \mathrm{IU} /$ day and 60,000 IU/week decreased disease activity in most CSU patients [32].

Among the various regimens, higher dosages of vitamin $\mathrm{D}$ (vitamin $\mathrm{D}_{3}$ of at least $28,000 \mathrm{IU} /$ week for 4-12 weeks, or vitamin $D_{2}$ of $140,000 \mathrm{IU} /$ week for 6 weeks) were reported to be effective. Although the available studies were relatively scarce, CSU patients with low serum vitamin D levels at baseline tended to show an improvement after receiving high dose vitamin $\mathrm{D}$ supplementation. Vitamin D has high safety margin. The tolerable upper intake levels are now 4000-10,000 IU/d for adults and the elderly, and lower for infants and young children $[48,49]$. According to our systematic review, even though there were not reported any adverse effect during vitamin $\mathrm{D}$ therapy, high dosage of vitamin $\mathrm{D}$ use should be concerned about safety. Measurement of serum vitamin D levels may be useful for safety monitoring and determining relationship to the treatment outcome, and it should be concerned about potential adverse effect at serum 25(OH)D levels greater than $50 \mathrm{ng} / \mathrm{ml}(125 \mathrm{nmol} /$ liter) [48].

Vitamin D supplementation was reported for other skin diseases. A meta-analysis by Kim et al. of 4 randomized, double-blind, placebo-controlled trials showed that the SCORAD index and EASI score of atopic dermatitis patients decreased significantly after vitamin D supplementation [50]. Lim et al. compared the vitamin D 
levels of patients with and without acne in a case-control study combined with a randomized controlled trial [46]. Improvements in inflammatory lesions were noted after vitamin D supplementation in 39 acne patients with 25(OH)D deficiency. Abou-Raya et al. randomized 267 patients with SLE to receive either vitamin $\mathrm{D}_{3}$ (2000 IU daily) or a placebo. At 12 months of treatment, there was a significant decrease in the pro-inflammatory cytokines levels (i.e., IL-1, IL-6, IL-18 and TNF- $\alpha$ ), anti-dsDNA, $\mathrm{C} 4$, fibrinogen, von Willebrand factor, and disease activity scores of the treatment group compared to the placebo group [51].

This systematic review has some limitations. First, there are small numbers of relevant studies. Second, few studies are RCTs; and variety in the individualized vitamin D supplementation regimens contribute to unsettle treatment results.

\section{Conclusions}

Most studies showed that CSU patients had significantly lower serum vitamin D levels than the controls $[14,18$, $20,21,23-25,28,29,31-33]$. However, this relationship does not prove causation. Data from a limited number of studies showed that the responders tended to be CSU patients with low serum vitamin D at baseline who received high-dose vitamin $\mathrm{D}$ supplementation regimens. For recalcitrant CSU patients with low serum vitamin D levels, a high dose of vitamin D supplements for 4-12 weeks may be used as an adjunctive treatment. Well-designed randomized placebo-controlled studies should be performed to determine the cut-off levels for vitamin $\mathrm{D}$ supplementation and treatment outcomes.

\begin{abstract}
Abbreviations
1,25(OH) 2 D: 1,25-dihydroxyvitamin D; 25(OH)D: 25-hydroxyvitamin D; BMl: body mass index; CIU: chronic idiopathic urticaria; CSU: chronic spontaneous urticaria; CU: chronic urticaria; GC: group-specific component; IL: interleukin; RCT: randomized controlled trial; SLE: systemic lupus erythematosus; SNPS: single nucleotide polymorphisms; Treg cells: regulatory T cells; UAS: urticaria activity score; UK: United Kingdom; VDBP: vitamin D binding protein; VDR: vitamin $\mathrm{D}$ receptor.
\end{abstract}

\section{Authors' contributions}

SA performed literature search of electronic databases. KK and SA screened articles for eligibility based on the inclusion criterion and assessed the risk of bias. PT and SA reviewed and extracted information from the eligible full-text articles. KK, PT, and LC contributed to the analysis of the results and to the writing of the manuscript. All authors read and approved the final manuscript.

\section{Author details}

${ }^{1}$ Department of Dermatology, Faculty of Medicine Siriraj Hospital, Mahidol University, 2 Wanglang Road, Bangkoknoi, Bangkok 10700, Thailand. ${ }^{2}$ Division of Endocrinology and Metabolism, Department of Medicine, Faculty of Medicine Siriraj Hospital, Mahidol University, Bangkok, Thailand.

\section{Acknowledgements}

The authors gratefully acknowledge Dr. Saowalak Hunnangkul, Ph.D. Biostatistician, for assistance with the statistical analyses.

\section{Competing interests}

The authors declare that they have no competing interests.

\section{Availability of data and materials}

All data generated or analysed during this study are included in this published article.

Consent for publication

Not applicable.

\section{Ethics approval and consent to participate}

The study protocol was approved by Siriraj Institutional Review Board, protocol No. 586/2560(Exempt).

\section{Funding}

This research did not receive any specific grants from funding agencies in the public, commercial, or not-for-profit sectors.

\section{Publisher's Note}

Springer Nature remains neutral with regard to jurisdictional claims in published maps and institutional affiliations.

Received: 1 August 2018 Accepted: 16 November 2018

Published online: 04 December 2018

\section{References}

1. Zuberbier T, Aberer W, Asero R, Bindslev-Jensen C, Brzoza Z, Canonica GW, et al. The EAACI/GA(2) LEN/EDF/WAO Guideline for the definition, classification, diagnosis, and management of urticaria: the 2013 revision and update. Allergy. 2014;69:868-87.

2. Rosen CJ. Clinical practice. Vitamin D insufficiency. N Engl J Med. 2011;364:248-54.

3. Ko JA, Lee BH, Lee JS, Park HJ. Effect of UV-B exposure on the concentration of vitamin D2 in sliced shiitake mushroom (Lentinus edodes) and white button mushroom (Agaricus bisporus). J Agric Food Chem. 2008;56:3671-4.

4. Deluca HF, Cantorna MT. Vitamin D: its role and uses in immunology. FASEB J. 2001;15:2579-85.

5. Yu C, Fedoric B, Anderson PH, Lopez AF, Grimbaldeston MA. Vitamin $\mathrm{D}$ (3) signalling to mast cells: a new regulatory axis. Int J Biochem Cell Biol. 2011;43:41-6.

6. Hata TR, Kotol P, Boguniewicz M, Taylor P, Paik A, Jackson M, et al. History of eczema herpeticum is associated with the inability to induce human beta-defensin (HBD)-2, HBD-3 and cathelicidin in the skin of patients with atopic dermatitis. Br J Dermatol. 2010;163:659-61.

7. Kongsbak M, von Essen MR, Levring TB, Schjerling P, Woetmann A, Odum N, et al. Vitamin D-binding protein controls T cell responses to vitamin D. BMC Immunol. 2014;15:35.

8. Cheng HM, Kim S, Park GH, Chang SE, Bang S, Won CH, et al. Low vitamin $D$ levels are associated with atopic dermatitis, but not allergic rhinitis, asthma, or IgE sensitization, in the adult Korean population. J Allergy Clin Immunol. 2014;133:1048-55.

9. Di Filippo P, Scaparrotta A, Rapino D, Cingolani A, Attanasi M, Petrosino $\mathrm{Ml}$, et al. Vitamin D supplementation modulates the immune system and improves atopic dermatitis in children. Int Arch Allergy Immunol. 2015;166:91-6.

10. Baroni E, Biffi M, Benigni F, Monno A, Carlucci D, Carmeliet G, et al. VDRdependent regulation of mast cell maturation mediated by 1,25-dihydroxyvitamin D3. J Leukoc Biol. 2007;81:250-62.

11. Powe CE, Evans MK, Wenger J, Zonderman AB, Berg AH, Nalls M, et al. Vitamin D-binding protein and vitamin D status of black Americans and white Americans. N Engl J Med. 2013;369:1991-2000.

12. Zhang J, Chalmers MJ, Stayrook KR, Burris LL, Wang Y, Busby SA, et al. DNA binding alters coactivator interaction surfaces of the intact VDRRXR complex. Nat Struct Mol Biol. 2011;18:556-63.

13. Bizzaro G, Antico A, Fortunato A, Bizzaro N. Vitamin D and autoimmune diseases: is vitamin D receptor (VDR) polymorphism the culprit? Isr Med Assoc J. 2017;19:438-43. 
14. Nasiri-Kalmarzi R, Abdi M, Hosseini J, Babaei E, Mokarizadeh A, Vahabzadeh Z. Evaluation of 1,25-dihydroxyvitamin D3 pathway in patients with chronic urticaria. QJM. 2018;111(3):161-9.

15. Abuzeid WM, Akbar NA, Zacharek MA. Vitamin D and chronic rhinitis. Curr Opin Allergy Clin Immunol. 2012;12:13-7.

16. Osborne NJ, Ukoumunne OC, Wake M, Allen KJ. Prevalence of eczema and food allergy is associated with latitude in Australia. J Allergy Clin Immunol. 2012;129:865-7.

17. Searing DA, Leung DY. Vitamin D in atopic dermatitis, asthma and allergic diseases. Immunol Allergy Clin N Am. 2010;30:397-409.

18. Abdel-Rehim AS, Sheha DS, Mohamed NA. Vitamin D level among Egyptian patients with chronic spontaneous urticaria and its relation to severity of the disease. Egypt J Immunol. 2014;21:85-90.

19. Ariaee N, Zarei S, Mohamadi M, Jabbari F. Amelioration of patients with chronic spontaneous urticaria in treatment with vitamin D supplement. Clin Mol Allergy. 2017;15:22.

20. Chandrashekar L, Rajappa M, Munisamy M, Ananthanarayanan PH, Thappa DM, Arumugam B. 25-Hydroxy vitamin D levels in chronic urticaria and its correlation with disease severity from a tertiary care centre in South India. Clin Chem Lab Med. 2014;52:115-8.

21. Grzanka A, Machura E, Mazur B, Misiolek M, Jochem J, Kasperski J, et al. Relationship between vitamin D status and the inflammatory state in patients with chronic spontaneous urticaria. J Inflamm (Lond). 2014;11:2.

22. Lee SJ, Ha EK, Jee HM, Lee KS, Lee SW, Kim MA, et al. Prevalence and risk factors of urticaria with a focus on chronic urticaria in children. Allergy Asthma Immunol Res. 2017:9:212-9.

23. Movahedi M, Tavakol M, Hirbod-Mobarakeh A, Gharagozlou M, Aghamohammadi A, Tavakol Z, et al. Vitamin D deficiency in chronic idiopathic urticaria. Iran J Allergy Asthma Immunol. 2015;14:222-7.

24. Oguz Topal I, Kocaturk E, Gungor S, Durmuscan M, Sucu V, Yildirmak $\mathrm{S}$. Does replacement of vitamin $\mathrm{D}$ reduce the symptom scores and improve quality of life in patients with chronic urticaria? J Dermatol Treat. 2016;27:163-6.

25. Rasool R, Masoodi KZ, Shera IA, Yosuf Q, Bhat IA, Qasim I, et al. Chronic urticaria merits serum vitamin D evaluation and supplementation; a randomized case control study. World Allergy Organ J. 2015;8:15.

26. Rorie A, Goldner WS, Lyden E, Poole JA. Beneficial role for supplemental vitamin D3 treatment in chronic urticaria: a randomized study. Ann Allergy Asthma Immunol. 2014;112(4):376-82.

27. Sindher SB, Jariwala S, Gilbert J, Rosenstreich D. Resolution of chronic urticaria coincident with vitamin D supplementation. Ann Allergy Asthma Immunol. 2012;109:359-60.

28. Thorp WA, Goldner W, Meza J, Poole JA. Reduced vitamin D levels in adult subjects with chronic urticaria. J Allergy Clin Immunol. 2010;126:413.

29. Woo YR, Jung KE, Koo DW, Lee JS. Vitamin D as a marker for disease severity in chronic urticaria and its possible role in pathogenesis. Ann Dermatol. 2015;27:423-30.

30. Wu CH, Eren E, Ardern-Jones MR, Venter C. Association between micronutrient levels and chronic spontaneous urticaria. Biomed Res Int. 2015;2015:926167.

31. Boonpiyathad T, Pradubpongsa P, Sangasapaviriya A. Vitamin D supplements improve urticaria symptoms and quality of life in chronic spontaneous urticaria patients: a prospective case-control study. DermatoEndocrinology. 2016;8:983685

32. Dabas G, Kumaran MS, Prasad D. Vitamin D in chronic urticaria: unrevealing the enigma. Br J Dermatol. 2017;177:47-8.

33. Rather $S$, Keen A, Sajad P. Serum levels of 25-hydroxyvitamin D in chronic urticaria and its association with disease activity: a case control study. Indian Dermatol Online J. 2018;9:170-4.
34. Tsai TY, Huang YC. Vitamin D deficiency in patients with chronic and acute urticaria: a systematic review and meta-analysis. J Am Acad Dermatol. 2018:79:573-5.

35. Wang $X$, Li $X$, Shen $Y$, Wang $X$. The association between serum vitamin $D$ levels and urticaria: a meta-analysis of observational studies. G Ital Dermatol Venereol. 2018;153:389-95.

36. Hypponen E, Power C. Hypovitaminosis D in British adults at age $45 \mathrm{y}$ : nationwide cohort study of dietary and lifestyle predictors. Am J Clin Nutr. 2007:85:860-8.

37. Kechichian E, Ezzedine K. Vitamin D and the skin: an update for dermatologists. Am J Clin Dermatol. 2018:19:223-35.

38. Holick MF. The vitamin D deficiency pandemic: approaches for diagnosis, treatment and prevention. Rev Endocr Metab Disord. 2017:18:153-65.

39. van Schoor NM, Lips P. Worldwide vitamin D status. Best Pract Res Clin Endocrinol Metab. 2011;25:671-80.

40. Heine G, Hoefer N, Franke A, Nothling U, Schumann RR, Hamann L, et al Association of vitamin $D$ receptor gene polymorphisms with severe atopic dermatitis in adults. Br J Dermatol. 2013:168:855-8.

41. Bergler-Czop B, Brzezinska-Wcislo L. Serum vitamin D level-the effect on the clinical course of psoriasis. Postepy Dermatol Alergol. 2016;33:445-9.

42. Upala S, Sanguankeo A. Low 25-hydroxyvitamin D levels are associated with vitiligo: a systematic review and meta-analysis. Photodermatol Photoimmunol Photomed. 2016;32:181-90.

43. Giuggioli D, Colaci M, Cassone G, Fallahi P, Lumetti F, Spinella A, et al. Serum 25-OH vitamin D levels in systemic sclerosis: analysis of 140 patients and review of the literature. Clin Rheumatol. 2017;36:583-90.

44. Aksu Cerman A, Sarikaya Solak S, Kivanc Altunay I. Vitamin D deficiency in alopecia areata. Br J Dermatol. 2014;170:1299-304.

45. Wu PW, Rhew EY, Dyer AR, Dunlop DD, Langman CB, Price $H$, et al. 25-hydroxyvitamin $D$ and cardiovascular risk factors in women with systemic lupus erythematosus. Arthritis Rheum. 2009;61:1387-95.

46. Lim SK, Ha JM, Lee YH, Lee Y, Seo YJ, Kim CD, et al. Comparison of vitamin $\mathrm{D}$ levels in patients with and without acne: a case-control study combined with a randomized controlled trial. PLOS ONE. 2016;11:0161162.

47. Muehleisen B, Bikle DD, Aguilera C, Burton DW, Sen GL, Deftos LJ, et al. PTH/PTHrP and vitamin D control antimicrobial peptide expression and susceptibility to bacterial skin infection. Sci Transl Med. 2012:4:135ra66-ra66.

48. Ross AC, Manson JE, Abrams SA, Aloia JF, Brannon PM, Clinton SK, et al. The 2011 report on dietary reference intakes for calcium and vitamin D from the Institute of Medicine: what clinicians need to know. J Clin Endocrinol Metab. 2011:96:53-8.

49. Pludowski P, Holick MF, Grant WB, Konstantynowicz J, Mascarenhas MR, Haq A, et al. Vitamin D supplementation guidelines. J Steroid Biochem Mol Biol. 2018;175:125-35.

50. Kim MJ, Kim SN, Lee YW, Choe YB, Ahn KJ. Vitamin D status and efficacy of vitamin D supplementation in atopic dermatitis: a systematic review and meta-analysis. Nutrients. 2016:8:789.

51. Abou-Raya A, Abou-Raya S, Helmii M. The effect of vitamin D supplementation on inflammatory and hemostatic markers and disease activity in patients with systemic lupus erythematosus: a randomized placebocontrolled trial. J Rheumatol. 2013;40:265-72.

Ready to submit your research? Choose BMC and benefit from

- fast, convenient online submission

- thorough peer review by experienced researchers in your field

- rapid publication on acceptance

- support for research data, including large and complex data types

- gold Open Access which fosters wider collaboration and increased citations

- maximum visibility for your research: over 100M website views per year

At BMC, research is always in progress.

Learn more biomedcentral.com/submissions 